\title{
Necropolítica no campo do HIV: algumas reflexões a partir do estigma da Aids
}

\author{
Necropolitics in the field of HIV: \\ some reflections from the stigma of AIDS
}

Felipe Cazeiro (http://orcid.org/0000-0002-1225-2884) ${ }^{1}$

Geórgia Sibele Nogueira da Silva (https://orcid.org/0000-0002-5716-6226) ${ }^{1}$

Emilly Mel Fernandes de Souza (https://orcid.org/0000-0002-5109-5025) ${ }^{1}$

\footnotetext{
${ }^{1}$ Universidade Federal do Rio Grande do Norte. Av. Sen. Salgado Filho, 3000, Lagoa Nova. 59078 970 Natal RN Brasil. felipecazeirodasilva@

gmail.com
}

\begin{abstract}
The article aims to raise reflections about the necropolitics directed to HIV/AIDS in Brazil from a set of rationalities that permeate the processes of configuration of the governmental agenda, treatment of the disease, and the policies and technologies involved. For this purpose, a non-systematic theoretical review was carried out from a threefold aspect: the stigma of AIDS, necropolitics, and life politics. We concluded that life politics, as opposed to necropolitics, contributes to the defense of human rights and health, above all, to the demystification of stigma and the politics of enmity historicized in AIDS.
\end{abstract}

Key words Death, Life, Public Policy, HIV, AIDS
Resumo O artigo intenta levantar reflexões sobre a necropolítica direcionada ao HIV/Aids no Brasil a partir de um conjunto de racionalidades que perpassam os processos de configuração da agenda governamental, tratamento da doença e as politicas e tecnologias envolvidas. Para tanto, foi realizada uma revisão teórica não-sistemática a partir de um tríplice aspecto: o do estigma da aids, o da necropolítica e o da política da vida. Concluiu-se que a política da vida como contraposição à necropolítica contribui para a defesa dos direitos humanos e da saúde, sobretudo para a desmistificação do estigma e da política de inimizade historicizada na Aids.

Palavras-chave Morte, Vida, Politicas Públicas, HIV, Aids 


\section{Introdução}

Desde os primórdios do surgimento do HIV/ Aids, nos anos 1980, foram notificados aproximadamente 966.058 casos de HIV no Brasil ${ }^{1}$. Durante este período, em distintos governos, diversas políticas e ações públicas foram construídas para o enfrentamento da doença.

Pelas vias de Bourdieu ${ }^{2}$, Agostini et al. ${ }^{3}$ discutem que uma crise é marcada por diferenças de poder, próprias dos agentes e instituições num determinado campo, configurando-se como um fenômeno não linear, pluridimensional e com pelo menos três interdependências: econômica, política e social.

Temporalmente, alguns autores ${ }^{3,4}$ demarcam 2013 como ponto de significância da crise brasileira e demonstram a reemergência da epidemia de aids a partir de sua crescente tendência a mortalidade, bem como da crise política que a intercede, sem, contudo, discutir o processo de estigma como eixo central para esta crise e sua relação com a dinâmica de poder que a sustenta.

Neste sentido, procuraremos destrinchar esta crise a partir do estigma aids e sua tipologia de poder para reemergência contemporânea, pois como afirmou Simone Monteiro e Wilza Villela ${ }^{5}$ : "as pesquisas acerca das consequências do estigma e da discriminação nos agravos à saúde são escassas".

Reiteramos a fragilização das políticas sociais e o incentivo à sua privatização que vem sendo articulada desde o golpe de 2016 - processo que depôs a Presidenta democraticamente eleita Dilma Rousseff ${ }^{6}$ - produzindo contingenciamentos e supressões sobre as políticas de saúde. No caso do HIV, tal articulação caminha reduzindo as possibilidades de atenção integral e manutenção da política nacional de IST's/HIV/Aids ${ }^{3}$.

Não podemos ignorar, também, a eleição presidencial de 2018 que contribuiu para a amplificação dessa crise, sendo marcada por uma disputa de repertórios narrativos e midiáticos. De um lado, a defesa dos direitos humanos que vinha consolidando a resposta brasileira ao HIV desde o início. Por outro, discursos obscurantistas de extrema direita que maquinaram nas representações coletivas uma "agenda de valores morais", constituindo-se como uma "anti-agenda" que têm questionado e procurado banir categorias como "gênero", "diversidade sexual", "racismo" e "redução de danos", historicamente centrais à prevenção do HIV no Brasil ${ }^{7-9}$.

Desta forma, na interdependência econômica, estamos lidando com o desenvolvimento e aces- so da terapia antirretroviral potente retratando um dos aspectos mais tensos e complexos da interação entre sociedade civil, empresas, agências financiadoras, governos e suas agências reguladoras, pois este é um campo de negociações de diferentes interesses, atravessado por amplo processo de acumulação capitalista e agravado por particular universo multifacetado e financeiro-especulativo, especialmente para a indústria farmacêutica, seu sistema de concorrência e patentes ${ }^{10}$.

Por fim, no âmbito social, acrescenta-se a (re)produção de antagonismos e afetos políticos baseados no ódio e medo, segregando as pessoas simbolicamente a partir de suas posições políticas, além de desencadear uma reemergência do estigma da aids que deixam nebulosos os entendimentos sobre a doença, (re)configuram a aids distópica que vivemos e impõem desafios para enfrentá-la.

Neste cenário, o Sistema Único de Saúde (SUS) tem sido o mais afetado junto com a área da educação, destacando-se a aprovação da Emenda Constitucional no $95^{11}$ que congelou os investimentos em saúde e educação por 20 anos. Este fato atinge pontualmente a qualidade da oferta de serviços, bem como para que sejam realizados diversos desmontes.

Portanto, a quarta década da epidemia no país tem sido marcada por transformações nos discursos e nas estratégias de prevenção, tratamento e de assistência em HIV/Aids. Essas intervenções parecem responder a uma lógica de interesse tecnocrata e altamente biomédica, em detrimento da perspectiva assentada nos direitos humanos e na vulnerabilidade predominante nas décadas de 1990 e $2000^{12,13}$.

Posto isto, trazemos o conceito de necropolítica que tem sido acionado e entendido enquanto um conceito teórico, político, epistêmico e metodológico para explicar a soberania de um Estado neoliberal contemporâneo que subjuga a vida ao poder da morte e, por ser assim, reconfigura profundamente as relações políticas e sociais para criar existências e mundos a partir da morte.

Tomamos de empréstimo esse conceito elaborado pelo filósofo camaronês Achille Mbembe ${ }^{14,15}$, uma versão da biopolítica foucaultiana, que contribui para (re)pensar os processos políticos atuais no Brasil, bem como nos contextos caribenhos e latino-americanos, cujos países carregam, reiteram e modernizam elementos da colonialidade. O necropoder está intimamente implicado no poder de gestão da vida das populações e é parte integrante dele, como já alertava Michel Foucault ${ }^{16}$. 
Sem negar os avanços existentes, é importante chamar a atenção para os desafios que o novo cenário apresenta. Não apenas em termos técnicos e científicos, mas também éticos, estéticos e políticos. Neste sentido, tal conceito torna-se um importante aliado para questionar e refletir sobre os direcionamentos e sentidos atribuídos pelo governo brasileiro contemporâneo para a epidemia de HIV/Aids.

Assim, o objetivo deste artigo foi o de refletir sobre as relações entre a crise da epidemia atual e a resposta brasileira ao HIV dando enfoque para a reemergência do estigma da aids enquanto instrumento necropolítico.

Trata-se de um ensaio teórico oriundo das reflexões e revisões de literatura que foi produzido a partir do estado da arte de uma pesquisa qualitativa construcionista social à nível de mestrado em psicologia e intitulada Histórias Posit(hiv)as de Gays e Pessoas Trans: Dos Estigmas à Cidada$n i a^{17}$. Vincula-se aos campos das ciências humanas, sociais e da saúde, particularmente à uma sociologia da saúde desde uma ótica que problematiza a relação biopolítica da sociedade com os processos de saúde e doença.

Destarte, o referido texto traz elaborações teóricas e políticas com o protagonismo de um pesquisador negro, homossexual e soropositivo, portanto intimamente atravessado pelo campo. E de outro, uma pesquisadora, branca, heterossexual e soronegativa, que vivenciou enquanto psicóloga, o início da epidemia, implicando-se, desde então, com a vida destas pessoas. E uma pesquisadora, psicóloga, travesti, heterossexual e soronegativa que tem sentido e vivenciado o tratamento discriminatório que algumas instituições relegam para sua identidade de gênero imaginada como um vetor de transmissão do HIV.

\section{Reemergência do Estigma da aids enquanto ferramenta Necropolítica}

Dada a articulação discursiva jornalísticabiomédica-midiática no surgimento da aids que validou a doença como um câncer/peste gay, a partir da consigna científica Gay Related Imunne Deficiency - GRID (Imunodeficiência Relacionada a Gays ${ }^{18}$, vemos um conjunto de desdobramentos que funcionaram para responsabilizar o HIV e a aids à determinados grupos que eram estigmatizados, combatidos e assassinados rotineiramente. Em consequência, deu-se um processo de moralização, racialização e homossexualização do HIV ${ }^{19}$ promovendo a exclusão social, estigma e discriminação, demonstrando, assim, o potencial de colonização de uma doença.
Susan Sontag ${ }^{20}$, na publicação de seu livro Aids como Metáfora, buscou uma apreensão mais política e sociológica das construções metafóricas que acompanharam a aids e verificou que sua prevalência estava diretamente associada aos estigmas e preconceitos do que propriamente aos sinais e sintomas do vírus.

A genealogia metafórica da aids é dupla. Enquanto microprocesso, ela é encarada como o câncer: como uma invasão. Quando o que está em foco é a transmissão da doença, invoca-se uma metáfora mais antiga, que lembra a sífilis: a da poluição ${ }^{20}$.

Neste sentido, Sander Gilman ${ }^{21}$ aponta que a categorização da aids não se deu como a de uma infecção viral como foi com a hepatite B, mas como a de uma infecção sexualmente transmissível como a sífilis.

Em tal grau, as reações psicossociais na época foram as mais diversas, como a expulsão de soropositivos de suas cidades, principalmente as pequenas e rurais, pois a compreensão que se tinha, notadamente, pelas crenças cristãs, era a de uma justiça divina às 'sexualidades desviantes' e/ ou um mal encarnado no corpo que era preciso expurgar para limpar a sociedade ${ }^{19,22}$.

Nesse processo ocorre um alheamento em relação a esse "outro", que muitas vezes é depositário do que rejeitamos. No entanto, a prática do alheamento lhe retira a vida em vida: "[...] o alheamento consiste numa atitude de distanciamento, no qual a hostilidade é substituída pela desqualificação do sujeito como ser moral. Significa não vê-lo como alguém que deve ser respeitado em sua integridade física e moral"23.

Portanto, ao receber a condição positiva para o HIV, estas pessoas precisariam enfrentar o crível societário de se são criminosos, vítimas, promíscuos, prostitutas, se estão com os dias contados e assim por diante. Logo, o diagnóstico supera o campo clínico tornando-se, também, moral criminalístico e arraigado por ampla violência estrutural do Estado.

Paralelamente, Paul Farmer ${ }^{24}$, através de uma análise sobre a dinâmica do HIV/Aids no Haiti e seu contexto político e social, revela a doença como uma patologia do poder reiterada pela ausência de direitos humanos e pela vulnerabilidade social: “As violações dos direitos humanos não são acidentes; elas e seus efeitos não são distribuídos aleatoriamente. As violações dos direitos, na verdade, são sintomas de profundas patologias do poder e estão intimamente ligadas às condições sociais que geralmente determinam quem sofrerá os abusos e quem será protegido dos danos" ${ }^{24}$. 
Ao longo da história de nossa humanidade outras doenças têm sido estigmatizadas: peste negra no século XIV e o cólera no século XIX ${ }^{25}$. Entretanto, abordar a questão do HIV é também suscitar velhos (e novos) processos de estigmatização no qual sua dinâmica e amplitude, características específicas e morais envolvidas, demandam forças efetivas no desenho de estratégias de combate ao estigma e suas consequências para os agravos em saúde.

De antemão, é preciso compreender que o estigma não é uma qualidade fixa, mas um elemento de diferenciações sociais e individuais resultantes de uma construção sociocultural cujo processo é histórico, mutável e se estabelece nas relações de depreciação do outro ${ }^{25}$.

Assim como a doença em si, o estigma se constitui como uma questão central para o processo de saúde-doença dado que o artifício da estigmatização acompanhou e ainda acompanha determinados grupos sociais atuando enquanto promotor de adoecimento e sofrimento psíquico e social.

Como traz o Índice de Estigma em Relação às Pessoas Vivendo com HIV ${ }^{26}$, realizado em $2019 \mathrm{em}$ 7 capitais brasileiras, para $81 \%$ das pessoas entrevistadas, em sua maioria negras, ainda é extremamente difícil revelar que vivem com HIV e quase metade dos respondentes $(47,9 \%)$ declararam ter sido diagnosticados com algum problema de saúde mental nos últimos 12 meses.

O Índice de Estigma (Stigma Index) é uma ferramenta global aplicada em mais de 100 países e utilizada para detectar e medir a mudança de tendências em relação ao estigma e a discriminação relacionados ao HIV a partir da perspectiva das pessoas soropositivas.

O estudo ${ }^{26}$ apontou que $15,3 \%$ das pessoas entrevistadas afirmaram ter sofrido algum tipo de discriminação por parte de profissionais da saúde pelo fato de serem soropositivas, e que $51,9 \%$ possuem dúvidas ou têm certeza de que o sigilo de suas informações registradas nos prontuários está sendo violado. Além disso, um em cada 3 respondentes declararam ter vergonha de ser soropositivo para o HIV e se sentirem culpados por sua condição de saúde.

A partir disso, podemos conceber o estigma como um fenômeno psicossocial e vetor de sofrimento psíquico e social, pois a partir dele configuram-se intensas violências e violações por permitir visualizar o HIV em termos de risco apenas, afastando os diferentes aspectos coletivos e individuais que constituem as pessoas, ou seja, sem compreendê-las em sua integralidade e amparadas por direitos.
Erving Goffman ${ }^{27}$, teórico reconhecido sobre o conceito de estigma, considera-o enquanto um fenômeno socio-histórico profundamente depreciativo e que nas relações, ao mesmo tempo em que permite depreciar uma pessoa, pode admitir a "normalidade" de outra a partir de uma marca de valoração negativa.

Todavia, Richard Parker $^{28}$, interpela criticamente o conceito goffminiano de estigma e nos convida a avançar na compreensão desse conceito individualizante para pensá-lo "como uma espécie de processo social, fundamentalmente ligado ao poder e à dominação"25. Ou seja, passa de uma compressão que centra pouco nas possibilidades de agência dos sujeitos e grupos sociais para uma que se relaciona às questões de desigualdade social e considera os processos culturais, as estruturas de poder, abrindo espaço para as possibilidades de resistência.

De fato, o estigma e a estigmatização funcionam, literalmente, no ponto de intersecção entre cultura, poder e diferença - e é somente explorando as relações entre essas categorias diferentes que se torna possível entender o estigma e a estigmatização não simplesmente como fenômenos isolados, ou como expressões de atitudes individuais ou de valores culturais, e sim como centrais para a constituição da vida social ${ }^{28}$.

Tal perspectiva contribui para não cairmos nas armadilhas de se confundir vulnerabilidade com vitimização. A vitimização desmonta princípios como de igualdade e de solidariedade e se alimenta da memória da inferioridade e da teatralização da infelicidade ${ }^{29}$. Logo, a vulnerabilidade, assume uma perspectiva da igualdade e da dignidade contextualizando-as nos panoramas estruturais e sociais das injustiças, discriminações, explorações e violências que acentuam a expansão do $\mathrm{HIV}^{30}$.

Se observamos que a doença é definida a partir de sua evolução nos Estados Unidos e na Europa, tendo como base um modelo primeiro -mundista, podemos compreender as "exceções à regra" dos modelos de terceiro mundo e o "descaso" brasileiro ${ }^{31}$.

Paradoxalmente, nos últimos anos, têm emergido uma tendência global comprometida com o "fim da aids". Essa emergência, transitoriamente, é assentada entre o fortalecimento de iniciativas científicas, de descoberta de uma possível cura e o recrudescimento da biomedicalização e suas inovações (PEP-Profilaxia Pós-Exposição, PrEP-Profilaxia Pré-Exposição, Prevenção Combinada etc.) tendo como plano de fundo a meta ambiciosa do UNAIDS (90-90-90): 90\% diag- 
nosticados; $90 \%$ em tratamento para o HIV sem interrupção; e 90\% com supressão viral ${ }^{32}$.

Apesar disso, temos assistido o aumento da incidência de novos casos de HIV, do adoecimento por aids em extratos sociais oprimidos e o aumento do desemprego, da fome e da pobreza. Esta pauperização desnuda por si a contradição de se ter avançado no campo científico com as novas tecnologias mais potentes, visto que este avanço não alcançou os processos de vulnerabilização que atravessam diversas pessoas.

O boletim epidemiológico aids de $2019^{1}$ evidencia tal contradição quando demonstra que a população negra $(59,8 \%)$ continua a morrer mais pela aids do que a população branca $(39,5 \%)$. Neste recorte racial, quando falamos entre mulheres, percebe-se que a mortalidade por aids é maior entre mulheres negras (proporção de óbitos entre mulheres negras foi superior à de homens negros: $61,5 \%$ e 59,0\%, respectivamente). Demonstra, ainda, que é a população trans e de homossexuais que figura o topo da incidência de novos casos de HIV (51,3\% dos casos).

Estatisticamente, denota-se que tais populações, que já foram tratadas por termos transbordados de discriminação como "grupos de risco" ou mais "brandos" como "população-chave", constituem populações historicamente oprimidas que possuem seus direitos sistematicamente negados ou negligenciados e que sofrem diversas discriminações que se associam a do HIV como contração suplementar.

Um simples exemplo é a campanha de prevenção de carnaval de $2019^{33}$ que eliminou qualquer referência às pessoas LGBT's, população especialmente vulnerabilizada pela epidemia. Ao não intervir sobre estas dimensões, o Estado está a aplicar sua necropolítica, dividindo entre quem pode e tem condições para viver e quem deixará morrer $^{34}$. Necropolítica aplicada porque o projeto neoliberal do governo atual tende a concentrar ainda mais a renda e reduzir as políticas sociais, aumentando a miserabilidade e a morte, inclusive. E não é este um assunto para a saúde?

Constata-se, então, que eixos de estigma, vulnerabilidade e desigualdade social são estritamente determinantes para as infecções por HIV, principalmente pelo silenciamento do debate sobre a discriminação e o estigma que, aliados aos desmontes e contingenciamentos graduais do SUS, colocam o acesso e a permanência ao tratamento em ruínas, bem como dificultam as ações de prevenção das IST/HIV/Aids.

Compreendendo o estigma como uma intersecção do poder, podemos perceber o proces- so necropolítico que o acompanha a partir de retrocessos à nível macro: Decreto no 9.795, de 17 de maio de $2019^{35}$ que modifica a estrutura e nome do Departamento de IST, Aids e Hepatites Virais que passa a se chamar "Departamento de Doenças de Condições Crônicas e Infecções Sexualmente Transmissíveis", invisibilizando ainda mais a complexidade e especialidade da doença; Decreto no 9.759, de 11 de abril de $2019^{36}$ que extingue os canais de participação social e de entidades sociais em políticas públicas; e Decreto $\mathrm{n}^{\circ}$ 9.761, de 11 de abril de $2019^{37}$ que extingue a política de redução de danos no Brasil.

E a nível micro, tem-se a falta de medicamentos antirretrovirais, exames de CD4 e carga viral em algumas cidades, estados e regiões do Brasil ${ }^{38}$, a inexistência de campanhas e ações de prevenção e promoção da saúde em IST/HIV/Aids, bem como diversas articulações para modificações estruturais de programas locais/regionais como a proposta de desvinculação do Centro de Referência e Treinamento DST/Aids-SP do Programa Estadual de IST/Aids de São Paulo que é referência nacional e internacional para o manejo da doença ${ }^{39}$.

Achille Mbembe ${ }^{14,15}$ aponta que a fusão completa de guerra e política, até o ponto de se tornarem indistinguíveis uns dos outros, já foi argumentada como algo exclusivo ao Estado nazista. Podemos traçar semelhanças ao campo da aids se lembrarmos da proposta de criação de campos de confinamento de pessoas soropositivas pela Frente Nacional Francesa (extrema-direita) aproximando-se dos campos de concentração nazista em que Michael Pollak ${ }^{40}$ denominou de "Aidetórios" e Denise Jodelet ${ }^{41}$ de "Sidatorium".

Assim, o terror se converte numa forma de marcar a aberração no corpo político, e a política é lida tanto como a força móvel da razão quanto como a tentativa errante de criar um espaço em que o "erro" seria reduzido, a verdade, reforçada, e o inimigo, eliminado ${ }^{14,15}$.

Simultaneamente, Pedro Paulo Gomes Perei$\mathrm{ra}^{42}$, em o Terror e a Dádiva, através de um exercício etnográfico numa fraternidade para pessoas soropositivas (1998-1999) localizada em uma fazenda, encontra uma centena de pessoas subjugadas sob o clima de tensão, violência e medo, encoberto por práticas que simulavam troca e reciprocidade e em muitos aspectos se assemelhava às instituições absolutas dos exemplos de Goffman $^{43}$. Assim, ele nos alertava que a justiça punitiva trabalha com a realidade incorpórea: "o corpo continua sendo alvo de disputa, mas mergulhado em campo político, visto que as relações 
de poder têm alcance imediato sobre ele. A sujeição dos corpos não se dá apenas pelos instrumentos da violência, do uso de armas e do terror; ela incide sobre o corpo, é física sem, contudo ser violenta" ${ }^{33}$.

$\mathrm{O}$ que queremos demonstrar é que a aids enfrenta uma distopia desde sempre. Quando se trata dos grandes avanços nas respostas à doença, o que se percebe é que eles não foram fugazes em estancar o sangue derramado. Ao revés, acortinou uma falsa expectativa de vida - "sobrevida" - para encarnar no corpo um mundo possível de se viver e habitar, sem tomar conta das reais condições que impelem as subjetividades, os corpos soropositivos e não soropositivos, que continuam a não querer saber se estão ou não com HIV/ aids (aproximadamente 135 mil pessoas vivem com HIV e não sabem) $)^{44}$.

Na prática, a aids não é exatamente uma doença "de todos nós", uma vez que não estamos todos no mesmo patamar social frente a ela e as respostas, por vezes, ainda estão amparadas por uma matriz individualista e culpabilizante: "se fulano se infectou pelo HIV, é porque ele realizou um comportamento de risco. Logo, a 'culpa' é dele" ${ }^{\prime 4}$. Ou, como afirmou nosso atual presidente que o HIV não é problema dele e de seu governo, pois quem vive na vida "mundana" não deveria buscar o serviço público para se tratar ${ }^{46}$.

Percebe-se, portanto, que, na ideia de "grupo de risco", a grande estratégia foi isolar. Na ideia de comportamento de risco, a grande estratégia, foi o adestramento individual. Em oposição, a estratégia baseada no conceito de vulnerabilidade provocou um giro epistemológico, prático e político capaz de minimizar muitos efeitos negativos das estratégias anteriores para ampliar a prevenção. Contudo, os retrocessos vigentes reatualizam a ideia de risco pela articulação de um direcionamento persecutório ${ }^{47}$ que, através de sua tipologia dissimétrica de poder, implementa uma técnica de governo sobre a vida que objetiva "fazer viver e deixar morrer"34. Em outras palavras, explicam Fernando Seffner e Richard Parker ${ }^{48}$.

$\mathrm{O}$ momento atual da resposta à aids é marcado, pela dupla tensão entre o fazer viver (ampliação da oferta de exames para conhecimento da situação sorológica e oferta universal da medicação antirretroviral) e o deixar morrer (reforço das situações de estigma e discriminação as populações vulneráveis $)^{48}$.

Pensar que o modo de gerir a vida nos remete às condições maiores ou menores de exposição ao adoecimento também nos mobiliza para dialogar além dos dados estatísticos para buscar des- cobrir como determinados caminhos têm sido condenados à repetição.

Um exemplo disso foi a suspensão dos benefícios previdenciários que afetou milhares de pessoas, como as soropositivas ${ }^{49}$. Tais beneficiários soropositivos estão há anos fora do mercado de trabalho e enfrentam problemas crônicos de saúde. Assim, como é possível retirar um salário mínimo dessa pessoa e fazê-la voltar a trabalhar depois de tantos anos, já na faixa dos 50/60 anos?

Essa discussão chegou a Brasília e terminou não sem divergências - com a sanção do Projeto de Lei $10.159 / 2018^{50}$, encampado pelo movimento social, que prevê que pessoas com HIV/aids, aposentadas por invalidez, podem ser dispensadas da reavaliação pericial. Apesar do resultado, esta disputa revela novos desafios à vida soropositiva, ainda marcada pela dinâmica do estigma, do poder e da necropolítica.

É evidente que não temos mais uma sentença de morte diante do diagnóstico ou um óbito provisório (se garantido plenamente as condições de tratamento). Pelo menos, não da morte física, mas ainda lidamos com a presença da morte civil, "a pior forma de ostracismo que pode suportar um ser humano"31. A doença do preconceito e da estigmatização matando mais do que o vírus. Não seria esta uma forma de poder necropolítico?

Em síntese, o HIV/aids continua com o status de doença moral e estigmatizante cujo simbolismo é bastante letal e político. E se antes, o HIV surgia com uma morte anunciada. Hoje caminha gradualmente para um falecimento decretado! Averígua-se, deste modo, o direcionamento atual do governo brasileiro para encobrir a doença, constituindo-se como uma das facetas e inscrições de outras espécies do estigma: o da necropolítica. Sua operacionalização atesta uma política da morte e de precarização da vida, expondo a perversidade à qual um Estado pode passar a operar para a gestão da vida das pessoas.

Com isso, não podemos esquecer da matéria intitulada Polícia Civil "combate" a Aids prendendo travestis, publicada na Folha de São Paulo no dia $1^{\circ}$ de março de 1987, referindo-se a operação tarântula implementada na ditadura civil militar no Brasil como uma política de extermínio à LGBT, especialmente às travestis ${ }^{51}$.

Denota-se então, um tribunal da aids que, através de uma soberania, exerceria julgamento sobre a mortalidade e definição da vida por meio da implantação e manifestação do poder que tem produzido efeitos mais de três décadas depois se considerarmos que o Brasil é o país que mais mata pessoas trans ${ }^{9,52}$. 
emponente da cidadania. E mais, é preciso assentá-la em uma política da vida $^{31}$ contra a necropolítica que, coerente com o neoliberalismo e fascismo, minimiza a dimensão pública da responsabilidade pela saúde dos indivíduos.

\section{Política da Vida: Solidariedade, Reconhecimento, Cidadania e Direitos Humanos!}

Vivemos em um contexto em que mais do que conceber a morte para a aids, o grande desafio a ser aprendido, verdadeiramente, é possibilitar condições de vida com HIV/Aids, posto que cresce gradativamente o número de novos casos por ano (cerca de 40 mil) e morre-se tanto quanto nos períodos iniciais da epidemia no Brasil ${ }^{1}$.

Desta forma, o primeiro passo é trabalhar com a ideia de que a sociedade ainda não está preparada para conviver com as pessoas soropositivas e a partir disto elencar tarefas e intervenções. Ademais, é preciso superar a lógica biomédica do tratamento, pois quando a pessoa soropositiva acessa o sistema de saúde ela é notificada e engolida por ele. Sua vida torna-se e reduz-se à taxas de CD4 e Carga Viral, amparado por uma redoma estreitamente biológica e reduzida ao status Indetectável = Intransmissível mediado por Carga viral/Doença versus CD4/Saúde.

Se faz necessário, também, somar esforços para desmistificar a interface histórica deste vírus associado à parábola dos “ $5 \mathrm{H}$ ” de "homossexuais, heroinômanos, hemofílicos, haitianos e hookers (profissionais do sexo)' que assinalou um tipo de sexualidade (a homossexual), um viés de raça/ etnia (negritude e latinidade) e um gênero (masculino $)^{53}$.

Assim, saúde enquanto um conceito abrangente, convoca para o debate temas tão centrais para o fenômeno da aids como o estigma e o fortalecimento de atitudes solidárias para o resgate da bioética e recrudescimento da justiça, da democracia, da cidadania e do direito à vida. A organização da solidariedade continua sendo a chave para a abertura desse espaço abarcado pela política da vida para o HIV/Aids.
Mas, o que é a solidariedade? Nos restringindo ao sentido mais sociológico, é possível perceber que a cada época histórica e de acordo com a forma que cada corrente o aborda, o termo 'solidariedade' sofre mudanças em seus diversos sentidos. Ele é afetado por acontecimentos socioeconômicos, pelas mudanças de paradigma dominante ou pela adaptação à novas teorias, mas segue predominantemente em um sentido individualista e voluntarista ${ }^{54}$.

O contexto político contemporâneo é fortemente marcado pelo poder da financeirização das economias, com ascensão do conservadorismo, fascismo e do neoliberalismo, perdendo-se o significado de muitas das dimensões e instituições democráticas e humanitárias, especialmente neste contexto de desmonte do SUS.

Esquece-se, portanto, que o sucesso das estratégias de resposta brasileira ao HIV/Aids é reconhecido internacionalmente. O Brasil foi um dos primeiros países - e o único, considerando sua dimensão populacional - a adotar a distribuição pública gratuita de antirretrovirais em 1996 através da Lei no 9.313 , de 13 de novembro de $1996^{55}$.

Sic transit gloria mundi ("toda glória do mundo é transitória") e na epidemia da aids estamos, mais uma vez, enfrentando um contexto que se assemelha ao da década de 1980. Assim, a crise do HIV no Brasil não pode ser equacionada apenas a uma simples crise, mas notadamente pautada por um projeto necropolítico.

Se faz necessário, portanto, convocar esforços para quebrar antigas associações e construções que pareciam ser infindáveis para reforçar e reorganizar o lugar da solidariedade. Um pacto social em defesa do direito à vida. "O que nos evita de sermos uns indiferentes e nos torna um humano, ou humanidade, é a experiência da solidariedade" 18 .

Nesta perspectiva, a solidariedade permite uma fundamentação mais direta com as experiências coletivas e sociais e para a luta por reconhecimento tal qual pensava Axel Honneth ${ }^{56}$.

$\mathrm{O}$ conceito de reconhecimento originou-se na filosofia dialética de Hegel e na psicologia social materialista de Mead a partir de três dimensões da interação social (afetiva, jurídica e social). Contudo, Honneth ${ }^{56}$, buscando uma formulação complementar a discussão desses autores, (re) pensa as três dimensões como elemento de diferenciação conforme sua realização na rede dos afetos, dos direitos e da solidariedade.

Honneth $^{56}$ procurava abordar a solidariedade, sem indicá-la como um conceito comum, mas considerando-a através da autorrelação individual concomitante com a experiência de es- 
tima social. Assim, este conceito se aplica, especialmente, às relações de grupo que se originam na experiência de circunstâncias difíceis, pois, é o que permite, por exemplo, em situações de guerra e/ou resistência, a emergência de um objetivo prático comum que gera um plano intersubjetivo de valores.

Cada membro aprende a reconhecer, na mesma medida, o significado das capacidades e propriedades do outro e a "representar um acontecimento coletivo capaz de fundar relações espontâneas de interesse solidário para além dos limites sociais [...] $\mathrm{Na}$ experiência partilhada de grandes fardos e privações, origina-se uma nova estrutura de valores que permite aos sujeitos estimarem-se mutuamente por realizações e capacidades que antes não tinham importância social" ${ }^{16}$.

Desta forma, "relações dessa espécie podem chamar-se solidárias porque despertam a tolerância ante a particularidade individual de outra pessoa, mas também pelo interesse por essa particularidade" 56 .

Em sua conclusão, sobre seu esquema das três redes de reconhecimento, Honneth ${ }^{56}$ argumenta que toda pessoa tem a chance de fazer a experiência de si mesmo como valiosa para a sociedade e que, por isso, só as relações sociais poderiam ser traduzidas pelo conceito de solidariedade.

Mais do que uma utopia poética, a solidariedade é, principalmente, "uma posição política, uma concepção da democracia como vida cotidiana, uma definição da cidadania" ${ }^{15}$. Um movimento de garantia plena da dignidade do ser humano. É o que traz sentido para a discussão a respeito da função social da solidariedade diante do direito à saúde, do direito à vida e da luta constante contra as desigualdades sociais.

Deste modo, enfrentar a desigualdade social e a pobreza é também produzir resposta para o HIV/aids. O processo de luta por reconhecimento, do direito ao acesso universal a prevenção, diagnóstico e tratamento é considerado uma questão relevante aos direitos humanos desde os primórdios da epidemia ${ }^{57}$.

Nas palavras de Herbet Daniel ${ }^{31}$ : "A educação de que a doença é um problema comum de toda a humanidade, gera uma estrutura de enfrentamento de onde surgem as raízes da solidariedade social".

E, segundo Herbert de Souza ${ }^{58}$, o "Betinho", é preciso acabar com o mito da fatalidade e o caldo de cultura do terror. Não é a perspectiva da morte que dá sentido à nossas existências, mas a perspectiva da vida. É a partir dela que podemos construir um exemplo de mobilização para continuar difundindo uma outra visão sobre a epidemia que restaure a cura como perspectiva e a solidariedade como princípio.

\section{Interrogar o passado, presente e futuro: algumas considerações}

A partir dos argumentos empreendidos, procuramos estabelecer reflexões para a construção de respostas aos desafios à crise contemporânea no campo do HIV/Aids e, sobretudo, reforçar eixos de aprendizagem para conviver com as diferenças, preservar direitos e desenvolver a capacidade de enfrentar os desafios colocados, com consciência, solidariedade e visões éticas.

Quais os prejuízos que esse viés político de morte traz para a atenção à saúde? Compreender um pouco mais sobre as raízes dessas políticas pode nos ajudar a pensar em que medida elas podem provocar o afastamento com o sofrer humano, e por ser assim, como afirmou Achille Mbembe $^{59}$, contribuir para o acirramento do término da era do humanismo.

Enquanto a aids for vista como uma doença do "outro", as pessoas soropositivas continuarão a ser divididas entre vítimas e culpadas, a vivência de nossa sexualidade dividida entre legítima e desviante, e as estigmatizações continuarão fornecendo o fertilizante necessário para a guerra do mundo nessa patologia do poder.

Sem dúvidas, desde o seu anúncio, estamos diante de uma luta constante contra preconceitos arraigados, contra a morte em vida ou, pelo menos, da morte civil, da luta pelo direito de continuar vivo, apesar de soropositivo. Enquanto não enfrentarmos, também, o tabu da morte, do sexo, qualquer doença letal pode ser vista como uma possibilidade para o "outro" 2 . Continuar desmistificando a aids pode contribuir para promover novos sentidos que conduzam a história da epidemia de maneira mais justa e menos alheia.

O compromisso com o sofrer humano é uma das bases da solidariedade, é uma força política, talvez a única capaz de transformar o mundo como dizia Herbert Daniel ${ }^{31}$. Estamos falando do reencantamento das pessoas com a sua humanidade. Estamos compartilhando a esperança e o desejo de que possamos nos aproximar do sonho de uma sociedade em que haja liberdade e igualdade para ser diferente ${ }^{23}$. Estamos falando também em condições socioeconômicas, científicas, culturais, educacionais e políticas para tal. 


\section{Colaboradores}

F Cazeiro: concepção, coleta de dados, análise de dados, participação ativa na discussão dos resultados, elaboração do manuscrito, revisão e aprovação da versão final do trabalho. GS Nogueira da Silva: participação ativa na discussão dos resultados, revisão e aprovação da versão final do trabalho. EMF Souza: participação ativa na discussão dos resultados, revisão e aprovação da versão final do trabalho.

\section{Referências}

1. Brasil. Ministério da Saúde (MS). Boletim Epidemiológico de HIV/AIDS 2019. Brasília: MS; 2019.

2. Bourdieu P. Algumas propriedades dos campos. In: Bourdieu P. Questões de Sociologia. Rio de Janeiro: Marco Zero; 1983. p. 89-94.

3. Agostini R, Rocha F, Melo E, Maksud I. A resposta brasileira à epidemia de HIV/AIDS em tempos de crise. Cien Saude Colet 2019; 24(12):4599-4604.

4. Grangeiro A, Castanheira ER, Nemes MIB. A re-emergência da epidemia de aids no Brasil: desafios e perspectivas para o seu enfrentamento. Interface (Botucatu) 2015; 19(52):5-6.

5. Monteiro S, Villela WV. Estigma e Saúde. Rio de Janeiro: Fiocruz, 2013.

6. Löwy M. Da tragédia à farsa: o golpe de 2016 no Brasil. In: Jikings J, Doria K, Cleto M, organizadores. Porque gritamos Golpe? Para entender o impeachment e a Crise Política no Brasil. São Paulo: Boitempo; 2016. p. 61-67.

7. Ayres JRCM. Práticas educativas e prevenção de HIV/ Aids: lições aprendidas e desafios atuais. Interface (Botucatu) 2002; 6(11):11-24,

8. Paiva V. Sem mágicas soluções: a prevenção e o cuidado em HIV/AIDS e o processo de emancipação psicossocial. Interface (Botucatu) 2002; 6(11):25-38.

9. Galindo D, Cazeiro F, Serra AG, Souza, LL. LGBTS and Gender Banned? Genealogical Notes about Law Projects in Brazil. Psicol Estud 2017; 22(2):253-264.

10. Bastos FI. Aids na terceira década. Rio de Janeiro: Editora Fiocruz; 2006.

11. Brasil. Emenda Constitucional no 95, de 15 de dezembro de 2016. Altera o Ato das Disposições Constitucionais Transitórias, para instituir o Novo Regime Fiscal, e dá outras providências. Diário Oficial da União 2016; 15 dez.

12. Monteiro S, Brigeiro M, Villela W, Mora C, Parker R. Desafios do tratamento como prevenção do HIV no Brasil: uma análise a partir da literatura sobre testagem. Cien Saude Colet 2019; 24(5):1793-1807.

13. Ferraz D, Paiva V. Sexo, direitos humanos e Aids: uma análise das novas tecnologias de prevenção do HIV no contexto brasileiro. Rev Bras Epidemiol Colet 2015; 18(Supl. 1):89-103.

\section{Agradecimentos}

Este trabalho foi realizado apesar das dificuldades econômicas do país dos autores. Os autores querem, em geral, ressaltar a viva contribuição do Estado brasileiro atual para o desmonte das políticas de HIV/Aids conquistadas no Brasil e do futuro de uma completa e resistente geração.

14. Mbembe A. Necropolítica: biopoder, soberania, estado de exceção, política da morte. Arte Ensaios 2016, 32:123-151.

15. Mbembe A. Necropolítica. São Paulo: n-1 edições; 2018.

16. Foucault M. É preciso defender a sociedade. Lisboa: Livros do Brasil; 2006.

17. Cazeiro F. Histórias Posit(hiv)as de Gays e Pessoas Trans: Dos Estigmas à Cidadania [dissertação]. Natal: Universidade Federal do Rio Grande do Norte; 2019.

18. Daniel H, Parker R. AIDS: a terceira epidemia. São Paulo: Iglu Editora; 1991.

19. Perlongher N. O negócio do michê: prostituição viril em São Paulo. São Paulo. Brasiliens; 1987.

20. Sontag S. Doença como metáfora. Aids e suas metáforas. São Paulo: Companhia de Bolso; 1989.

21. Gilman SL. Disease and Representation - images of illness from madness to aids. Ithaca, Londres: Cornell University Press; 1991.

22. Parker R, Aggleton P. Estigma, Discriminação e Aids. Rio de Janeiro: ABIA; 2001.

23. Nogueira da Silva GS. AIDS: da estigmatização ao acolhimento da vida. In: Vilar RLA, Souza ECF, Milan EP, Castro JL, Freitas MR, Macedo MRC, organizadores. O contexto da Política para as DST, AIDS e Hepatites Virais. Natal: EDUFRN; 2011. p. 76-90.

24. Farmer P. Pathologies of power: health, human rights, and the new war against the poor. Berkeley: University of California Press; 2005.

25. Garcia S, Koyama MAH. Estigma, discriminação e HIV/Aids no contexto brasileiro, 1998 e 2005. Rev Saude Publica 2008; 42(Supl. 1):72-83.

26. Programa Conjunto das Nações Unidas sobre HIV/ AIDS (UNAIDS). Sumário Executivo. Índice de Estigma em relação às pessoas vivendo com HIV/AIDS - BRASIL [Internet]. 2019 [acessado 2020 jan 08]. Disponível em: https://unaids.org.br/2019/12/estudo -revela-como-o-estigma-e-a-discriminacao-impactam-pessoas-vivendo-com-hiv-e-aids-no-brasil/.

27. Goffman E. Estigma - notas sobre a manipulação do identidade deteriorada. Rio de Janeiro: LTC; 2004. 
28. Parker R. Interseções entre estigma, preconceito e discriminação na saúde pública mundial. In: Monteiro S, Villela W, organizadores. Estigma e Saúde. Rio de Janeiro: Ed. Fiocruz; 2013. p. 25-46.

29. Rosanvallon P. A Nova Questão Social: repensando o Estado Providência. Brasília: Instituto Teotônio Vilela; 1998.

30. Parker R. Na contramão da AIDS: Sexualidade, intervenção, política. São Paulo: Editora 34; 2000.

31. Daniel H. Anotações a margem do viver com AIDS. São Paulo: Hucitec; 1991.

32. Programa Conjunto das Nações Unidas sobre HIV/ AIDS (UNAIDS). 90-90-90 Uma meta ambiciosa de tratamento para contribuir para o fim da epidemia de AIDS [Internet]. 2015 [acessado 2019 out 02] Disponível em: https://unaids.org.br/wp-content/uploads/2015/11/2015_11_20_UNAIDS_TRATAMENTO_META_PT_v4_GB.pdf.

33. Brasil. Ministério da Saúde (MS). Prevenção ao HIV. Carnaval 2019. [acessado 2019 Mar 20]. Disponível em: http://portalarquivos.saude.gov.br/campanhas/ usecamisinha/.

34. Foucault M. Em defesa da sociedade. São Paulo: Martins Fontes; 1999.

35. Brasil. Decreto no 9.795, de 17 de maio de 2019. Aprova a Estrutura Regimental e o Quadro Demonstrativo dos Cargos em Comissão e das Funções de Confiança do Ministério da Saúde, remaneja cargos em comissão e funções de confiança, transforma funções de confiança e substitui cargos em comissão do Grupo-Direção e Assessoramento Superiores - DAS por Funções Comissionadas do Poder Executivo - FCPE. Diário Oficial da União 2019; 17 mai.

36. Brasil. Decreto no 9.759, de 11 de abril de 2019. Extingue e estabelece diretrizes, regras e limitações para colegiados da administração pública federal. Diário Oficial da União 2019; 11 abr.

37. Brasil. Decreto no 9.761, de 11 de abril de 2019. Aprova a Política Nacional sobre Drogas. Diário Oficial da União 2019; 11 abr.

38. Nações Unidas (ONU). Conferência sobre AIDS alerta para falta de remédios antirretrovirais na América Latina [Internet]. 2018 [acessado 2020 jan 08]. Disponível em: https://nacoesunidas.org/conferencia-sobre-aids -alerta-para-falta-de-remedios-antirretrovirais-na-america-latina/.

39. Agência de Notícias da Aids. Propostas de mudanças no CRT de São Paulo preocupam ativistas e usuários do serviço [Internet]. 2019 [acessado 2020 jan 08]. Disponível em: http://agenciaaids.com.br/noticia/ propostas-de-mudancas-no-crt-de-sao-paulo-preocupam-ativistas.

40. Pollak M. Os Homossexuais e a Aids: Sociologia de uma Epidemia. São Paulo: Estação Liberdade; 1990.

41. Jodelet D. Représentations sociales: un domaine en expansion. In: Jodelet D. Les représentations so-ciales. Paris: PUF; 1989. p. 31-61.

42. Pereira PPG. O terror e a dádiva. Goiânia: Editora Vieira, Cânone Editorial; 2004.

43. Goffman E. Manicômios, prisões e conventos. São Paulo: Perspectiva; 1974.

44. Brasil. Ministério da Saúde (MS). 135 mil brasileiros vivem com HIV e não sabem [Internet]. 2019 [acessado 2020 jan 08]. Disponível em: http://www.saude. gov.br/noticias/agencia-saude/46095-135-mil-brasileiros-vivem-com-hiv-e-nao-sabem.
45. Seffner F. O conceito de vulnerabilidade: uma ferramenta útil em seu consultório. Aletheia 1998; 7:53-58.

46. Johan A. "Não é problema meu", diz candidato sobre prevenção e tratamento de HIV [Internet]. 2019 [acessado 2019 maio 31]. Disponível em: https://revistaladoa.com.br/2018/09/noticias/nao-e-problemameu-diz-candidato-sobre-prevencao-e-tratamentode-hiv/.

47. Castiel LD, Dardet CA. A Saúde Persecutória: Os limites da responsabilidade. Rio de Janeiro: Editora Fiocruz; 2007.

48. Seffner F, Parker R. The waste of experience and precariousness of life: contemporary political moment of the Brazilian response to aids. Interface (Botucatu) 2016; 20(57):297-304.

49. British Broadcasting Corporation (BBC News) Brasil. 'Quem vai querer um funcionário com HIV?', diz homem que perdeu aposentadoria após 13 anos [Internet]. 2019 [acessado 2020 jan 08]. Disponível em: https:// epocanegocios.globo.com/Carreira/noticia/2019/07/ quem-vai-querer-um-funcionario-com-hiv-diz-homem-que-perdeu-aposentadoria-apos-13-anos.html.

50. Brasil. Senado Federal. Projeto de Lei no 10.159-B, de 2018. Altera a Lei no 8.213, de 24 de julho de 1991, para dispensar de reavaliação pericial a pessoa com HIV/aids aposentada por invalidez. Câmara dos Deputados 2018; 24 jul.

51. Cavalcanti C, Barbosa RB, Bicalho, PPG. Os Tentáculos da Tarântula: Abjeção e Necropolítica em Operações Policiais a Travestis no Brasil Pós-redemocratização. Psicol Cien Prof 2018; 38(n. esp. 2.):175-191.

52. Transgender Europe (TGEU). Trans Murder Monitoring/Observatório de Pessoas Trans Assassinadas [Internet]. 2017 [acessado 2020 jan 08]. Disponível em: https://dossies.agenciapatriciagalvao.org.br/dados-efontes/pesquisa/pessoas-trans-assassinadas/.

53. Pelúcio L, Miskolci R. A prevenção do desvio: o dispositivo da aids e a repatologização das sexualidades dissidentes. Sex Salud Soc Rev Latinoam 2009; 1:25-157.

54. Silva GM. Solidariedade (ainda) é um conceito central na sociologia (das organizações)? Mudanças conceituais e a questão do desenvolvimento. In: Anais do XXXV Encontro da ENPAD. Rio de Janeiro; 2011. p. $1-16$.

55. Brasil. Lei no 9.313, de 13 de novembro de 1996. Dispõe sobre a distribuição gratuita de medicamentos aos portadores do HIV e doentes de AIDS. Diário Oficial da União 1996; 13 nov.

56. Honneth A. Luta por reconhecimento: a gramática moral dos conflitos sociais. São Paulo: Ed. 34; 2003.

57. Brasil. Ministério da Saúde (MS). Direitos humanos e HIV/Aids: avanços e perspectivas para o enfrentamento da epidemia no Brasil. Brasília: MS; 2008.

58. Souza H. A cura da Aids. Rio de Janeiro: Relume-Dumará; 1994.

59. Mbembe A. The age of humanism is ending. Mail Guardian 2016: 1-6.

Artigo apresentado em 16/08/2019

Aprovado em 14/04/2020

Versão final apresentada em 16/04/2020

Editores-chefes: Romeu Gomes, Antônio Augusto Moura da Silva 